\title{
Investigative interviewing of suspected sex offenders: a review of what constitutes best practice
}

\author{
Julianne M. Read ${ }^{\dagger}$, Martine B. Powell ${ }^{t \dagger}$, Mark R. Kebbell ${ }^{\S}$ and \\ Rebecca Milne ${ }^{\ddagger}$ \\ †School of Psychology, Deakin University, Melbourne, Australia \\ ††(Corresponding author) School of Psychology, Deakin University, 221 Burwood Hwy, \\ Burwood, 3125, Victoria, Australia. Tel: 61-3-9244-6106; email: \\ martine.powell@deakin.edu.au \\ $\S A R C$ Centre of Excellence in Policing and Security, Griffith University, Brisbane, Australia \\ łInstitute of Criminal Justice Studies, University of Portsmouth, Portsmouth, England \\ Received 26 November 2008; revised and accepted 11 March 2009 \\ Keywords: investigative interviewing, police training, sexual offences, \\ suspect interviewing
}

Julianne Read is a forensic doctoral candidate in the School of Psychology, Deakin University who specialises in the area of suspect interviewing.

Martine Powell is Professor of Psychology, Deakin University. Her research has focused primarily on investigative interviewing of vulnerable witnesses, but more recently her work has expanded to include interviewing of suspects as well as models of policing related to sexual offences.

Mark Kebbell is Associate Professor and Chief Investigator at the ARC Centre of Excellence, Brisbane, Australia. His expertise and research is in the area of investigative psychology particularly the investigation and prosecution of serious crime.

Rebecca Milne is a chartered forensic psychologist and Principal Lecturer at the Institute of Criminal Justice Studies at the University of Portsmouth. Her primary expertise is in the area of investigative interviewing and police training.

International Journal of Police Science and Management, Vol. 11 No. 4, 2009, pp. 442-459. DOI: $10.1350 /$ ijps.2009.11.4.143

\section{Abstract}

Research on the topic of investigative interviewing of suspected sex offenders is still in its infancy, with the majority of work to date focusing on developing theories underlying confessions, and reflecting on the value of specific interview techniques that have been observed in the field. This paper provides a synthesis of the literature in order to produce a preliminary guide to best practice for the interviewing of this particular interviewee group. Specifically, this review is structured around five elements that should be considered when planning for and administering the interview. These elements include: (a) establishing rapport, (b) introducing the topic of concern, (c) eliciting narrative detail, (d) clarification/specific questions and (e) closure. The unique contribution of this paper is its practical focus, and its synthesis of findings across a variety of streams, including the general eyewitness memory literature, legislation and case law, therapeutic literature, and research specifically related to the interviewing of offenders (including confessions). At the conclusion of the review, recommendations are offered for further research.

\section{INTRODUCTION}

Police interviews with suspects are fundamental in criminal investigations. The aim 
of these investigative interviews (as with any police interview) is to gather evidence that will assist in establishing whether or not a criminal act has occurred, and (if an act is identified or acknowledged) to establish the context and nature of the act and the person who perpetrated it. Conducting effective and appropriate interviews with suspected sex offenders is particularly important for several reasons. First, compared with other types of offenders, persons charged with sexual offences are the least likely to plead guilty, are more likely to go to trial and are more likely to get an acquittal (Australian Bureau of Statistics [ABS], 2004; The Response to Rape, 1993). These findings are due in part to the strong societal stigma attached to this crime (McGrath, 1990; Quinn, Forsyth, \& Mullen-Quinn, 2004) and because in sexual abuse cases there is usually little physical evidence to corroborate the victim's or suspect's account of the incident.

Furthermore, sex offending is a crime associated with personality, interpersonal deficits and cognitive distortions that increase the likelihood that detail elicited in the interview will be misinterpreted and deemed unreliable (Fisher, Beech, \& Browne, 1999; Swaffer, Hollin, Beech, Beckett, \& Fisher, 1999; Ward, Hudson, Johnston, \& Marshall, 1997). In addition, the more vulnerable the person accused of the offence (whether this vulnerability be for emotional, cultural and/or intellectual reasons), the greater the likelihood of eliciting error and a false confession (Gudjonsson, 2003; Gudjonsson \& Clark, 1986; Richardson \& Kelly, 1995). Thus, interviews with sex offender suspects that are conducted appropriately (in accordance with the relevant legislation) ensure both innocent and guilty suspects are treated fairly and minimise the likelihood of eliciting false details and confessions (Gudjonsson, 2003).
Despite the importance of investigative interviews with alleged sex offenders, there is a paucity of literature in this area compared with that of other respondent groups (eg, child witnesses, adult witnesses). The majority of literature in the sex offender area has focused on developing theories underlying confessions, and the effectiveness of specific (isolated) interview techniques that have been observed in the field. Interview models have been developed (eg, Cognitive Interview, Conversation Management); however these provide very broad guidelines given that they apply to a range of respondent groups. To extend discussion in relation to sex offenders, this paper provides: (a) a description of the critical elements of investigative interviews with sex offenders that need to be considered when planning for and administering the interview, (b) a review of the available evidence to justify each element, and (c) practical instruction on how bestpractice principles can be applied. The unique contribution of this paper is its practical (albeit empirical) focus, and its synthesis of findings across a variety of streams, including the general eyewitness memory literature, legislation and case law, therapeutic literature and research specifically related to the interviewing of offenders (including confessions).

Overall, this review is structured around the five elements common to all investigative interview protocols. These include: (a) establishing rapport, (b) introducing the topic of concern, (c) eliciting narrative detail, (d) clarification/specific questions and (e) closure. Given that sex offenders are a heterogeneous group (including different typologies (Ward, Hudson, \& Marshall, 1996)), and that there is a paucity of prior interviewing research involving this group, the suggestions arising within this review should only be considered a general and tentative guide. 


\section{ESTABLISHING RAPPORT}

Most academics and clinicians in the area of interviewing (for investigative or assessment purposes) acknowledge that the establishment of a good rapport between the interviewer and interviewee is critical for maximising the accuracy and detail of information about embarrassing, sensitive or traumatic matters (Baldwin, 1992; Clarke \& Milne, 2001; Ede \& Shepherd, 2000; Kinsey, Pomeroy, \& Martin, 1948; Milne \& Bull, 1999; Poole \& Lamb, 1998; Powell \& Lancaster, 2003; Royal College of Psychiatrists, 2004; Shepherd, 1991; Vrij, 2003; Walters, 2002; Wilson \& Powell, 2001; Yeschke, 2003). Rapport is a broad term, referring to a relationship that is conducive to good communication. Although such a relationship needs to be maintained throughout the entire interview, its establishment is critical at the outset of the interview, before attempting to elicit evidential detail. For this reason, most interview protocols specify a distinct 'rapportbuilding' phase, which occurs after the initial greeting and prior to the introduction of the specific topic of concern.

Given that the aim of any investigative interview is to gather evidence regarding whether, how and by whom a criminal act has occurred, good rapport is that which assists in overcoming the barriers to effective elicitation of evidential detail. The literature suggests that there are three main barriers to eliciting reliable evidence. Each of these barriers is discussed in turn, along with associated goals and practical techniques for overcoming them.

The first barrier relates to emotional, social or motivational factors. Shame and fear of exposure are common emotions among persons who commit sexual crimes, which increase the likelihood of denial to oneself and others (Higendorf \& Irving, 1981; Royal College of Psychiatrists, 2004; Shepherd, 1993; Yeschke, 2003). This is true of all sex offender groups but particularly those who commit sexual abuse against children, which is regarded in most Western societies to be a particularly heinous crime (Hoyano \& Keenan, 2007). In order to encourage honest and detailed reporting, rapport needs to be established where the interviewee perceives that his or her experiences and perceptions will be heard, understood and not judged. Some authors propose that this style of interaction equates with being an advocate, to showing sympathy for the suspect, for minimising the seriousness of the alleged offence, or showing that the account is believed (Ellis, 1954; Inbau, Reid, \& Buckley, 1986; Yeschke). However, others contend that rapport can be effectively established without being deceptive about the process (eg, pretending to collude with the interviewee), without overstepping professional or ethical boundaries, or without diminishing the seriousness of the act or its impact on the victim (Ord, Shaw, \& Green, 2004; Powell \& Bartholomew, 2003; Royal College of Psychiatrists; Shepherd, 1993). The critical component of rapport seems to be the demonstration of respect of the interviewee. This is achieved by considering the interviewee's physical, emotional and cognitive needs (irrespective of what he or she may have done), and by establishing a genuine (sincere) relationship where the person perceives that he or she is being heard and not judged.

The importance of being respectful and establishing a sincere, supportive interview environment is highlighted by case studies documenting the prevalence of false confessions. Such confessionals have been shown to arise in contexts where the suspect felt intimidated, threatened or tired (Gudjonsson, 2003; Kassin \& Gudjonsson, 2004). The importance of being respectful and sincere is also supported by qualitative studies where convicted sex offenders have 
been asked about their reasons for confessing. Overwhelmingly, the most common response among convicted offenders in these studies is that the establishment of a supportive environment was conducive to the provision of an honest and detailed account because it increased their confidence to engage in the process (Gudjonsson \& Sigurdsson, 2000; Holmberg \& Christianson, 2002; Kebbell, Alison, Hurren, \& Mazerolle, in press; Kebbell, Hurren \& Mazerolle, 2006). Finally, the importance of a supportive, non-intimidating relationship is depicted in research showing that sex offenders (particularly those who molest children) have a strong internal need to confess their involvement so that others can understand the context in which their behaviour evolved (Gudjonsson \& Sigurdsson).

The second barrier to eliciting accurate and detailed evidence relates to language and cognitive limitations. Although some offenders have excellent social and communication skills, there is a small but growing body of international research demonstrating that young people who go on to become offenders (including sex offenders) are at high risk of experiencing unrecognised oral language impairments (Bryan, 2004; Bryan, Freer, \& Furlong, 2007; Sanger, Moore-Brown, \& Alt, 2000; Snow \& Powell 2004b; Snow \& Powell, 2005). Oral language (in the context of interviewing) refers to the individuals' ability to relay their experiences in a manner that maximises comprehension on the part of the listener (Stein \& Glenn, 1979). While a statistical association between oral language deficit and offending can be explained in part by a comanifestation of psychiatric illness (Dunsieth et al., 2004; Fazel, Sjostedt, Langstrom, \& Grann, 2007), it is also due to the fact that unidentified oral language impairments contribute to interpersonal deficits which in themselves heighten the risk of offending behaviour (see Snow \& Powell, 2004a, 2004b, 2005) Indeed, evidence shows that sex offenders have fewer social skills and more communication deficits than non-offenders (Emmers-Sommer et al., 2004), with impaired social functioning being common among those who sexually offend against children (Cohen et al., 2002).

Oral language deficits create a significant barrier within interviews because of their strong association with suggestibility ${ }^{1}$ (Bruck \& Melnyk, 2004; Gudjonsson, 2003) and the likelihood that the interviewee will (unintentionally) give responses that are misinterpreted, inaccurate and not believed (Eades, 1992; Nield, Milne, Bull, \& Marlow, 2003; Powell, 2000). Unfortunately, language deficit is not easily detected by professionals, as individuals with such deficits (through normal everyday interactions) learn ways to mask them to avoid embarrassment arising from their deficiencies. Masking behaviours include providing stereotypical or brief responses to questions, acquiescing in closed questions (eg, head nodding), or showing signs of apathy or disinterest (Snow \& Powell, 2004a).

Apart from using appropriate questioning techniques (which will be discussed later in this paper), the most reliable way of minimising the detrimental impact of language impairment is to put the interviewee into the role (right at the outset of the interview) as a valued and competent informant (Fisher \& Geiselman, 1992). Research in the child eyewitness memory arena has empirically demonstrated that encouraging interviewees (via the use of open-ended questions) to do most of the talking in the initial rapport-building stage $^{2}$ enhances the likelihood that they will provide elaborate responses when subsequently asked about the alleged offence (Roberts, Lamb, \& Sternberg, 2004; Sternberg et al., 1997). The proposed mechanism 
for this finding is that it primes the interviewees (particularly those who are not used to providing elaborate accounts of events in everyday life) to the open-ended interview process (ie, it teaches them to talk), and creates a relationship where they perceive that they are being listened to and not judged. The added advantage of encouraging the suspect to talk during the non-substantive or pre-interview phase is that it provides an objective point of comparison to interpret later interviewee behaviour (Snow \& Powell, 2005). For example, if the suspect demonstrates highly complex and elaborate language skills in the rapport-building stage yet provides a lack of detail about the offence, one can conclude that the reason for the change in behaviour is due to poor memory or emotional factors rather than language limitations per se.

The final barrier to eliciting accurate and detailed evidence in an investigative interview relates to lack of clarity regarding process issues. Process issues include the function of the interview (ie, to gather information) and the interviewee's role within it (ie, to do most of the talking). Misunderstandings in relation to the elements required for successful prosecution of sex offences and the evidential role of interviews can increase the likelihood that the interviewee will (unintentionally) provide false information that is self-incriminating. For example, in everyday conversation, it is normal within most cultural groups for persons to embellish accounts with inaccurate details and to agree with inaccurate statements for the purpose of maintaining listener attention or a desirable social position. If process issues (eg, matters regarding confidentiality, the interviewee's rights) are established early in the interview, this will minimise the detrimental effect of emotional and language barriers by portraying a sense of the importance of the interview and the fact that the interviewee is being treated fairly (Fisher \& Geiselman, 1992).

The establishment of process issues related to the rights of the interviewee is essential (in most jurisdictions) for enabling the interview to be tendered in court as evidence (Heydon, 2004; Yeschke, 2003). However, a transparent interview process needs to extend beyond the requirements imposed by legislation. Experts contend that interviewees will be better informants if they fully understand their role within the interview and what is expected of them (Fisher \& Geiselman, 1992; Milne \& Bull, 1999; Stephenson \& Moston, 1993). Establishing interview 'ground rules' is particularly important among those persons who may have little experience with forensic interviews, and where the conversational rules violate those used in typical everyday interactions (Powell, Fisher, \& Wright, 2005). For example, when conversing about experiences in everyday contexts, it is generally considered desirable for speakers to be concise (ie, not to relay highly specific information that is unrelated to the central story (Grice, 1975)), and to avoid correcting or disagreeing with any individual who is in a position of considerable authority (Paddock \& Terranova, 2001). Further, it is acceptable in everyday conversations to edit or withhold information if it is perceived to be irrelevant or if it contradicts an earlier response. None of these 'everyday' conversational rules is appropriate in a forensic context, where the provision of accurate and detailed evidence outweighs the importance of brevity and normal social etiquette. Indeed, in terms of prosecuting sexual offences it is sometimes the seemingly irrelevant or peripheral details that contribute to successful case outcome. Thus, 'ground rules' are essential in explicitly allowing the suspect to break those conventional conversational barriers to communication. 


\section{INTRODUCING THE TOPIC OF CONCERN}

Once initial rapport is established, the topic of concern (ie, the allegation) needs to be introduced. To the interviewee, this may not appear to be a separate phase of the interview per se. If the rapport-building questions were about the suspect and his background, then the transition to this phase may merely be a subtle change in direction of the questions to focus more on the offence. In cases where the rapportbuilding questions were about a completely irrelevant topic, however, the interviewer may need to make an explicit statement about the shift in interview topic to the matter of concern.

As with rapport building, this is a critical phase of the interview, particularly in cases of alleged sexual abuse where the interviewee denies any wrongdoing. In fact, some trainers (eg, Powell, Fisher, \& Wright, 2005) suggest that lack of preparation regarding how to raise the topic of concern is a major reason for poor interview outcome. Without adequate preparation relating to this phase, interviewers are at risk of being too confrontational (which evokes anger and distrust) or of being too leading. Giving too much information in the early stages of the interview is problematic because it increases the likelihood of aggression or denial (if the suspect senses that the interviewer has strong preconceptions about what happened) and provides suspects with information that could potentially be used to create a credible, but false version of the events to exonerate themselves of wrongdoing or to get the interview over with quickly (Bennis, Berlew, Schein, \& Steele, 1973; Hartwig, Granhag, Stromwall, \& Kronkvist, 2006).

Unfortunately, there has been a paucity of discussion in the literature regarding how best to raise the topic of concern with a suspected sex offender. Within the witness interview literature, Powell (2003) and Powell and Snow (2007b) have emphasised the importance (when raising prior information) of: (a) being direct (ie, not 'fishing' for a disclosure), (b) not assuming that any prior information that led to the concern is true and (c) avoiding raising issues of contention. The first two recommendations apply to interviewing suspects, but not the last one. Rather than avoiding the alleged offence, there is a legal requirement (in most jurisdictions) to raise the nature of the allegation at the outset. For example, in Australia police have a legal duty to disclose the 'nature of the crime' about which the suspect is being interrogated (Heydon, 2004). Similarly, in the United States, under the Sixth Amendment of the US Constitution, the accused has the right to be 'informed of the nature and cause of the accusation'. Under this rule, it is stated that 'No indictment is sufficient if it does not allege all of the ingredients that constitute the crime'; however 'an indictment in general language is good if the unlawful conduct is described so as reasonably to inform the accused of the nature of the charge sought to be established against him'. Likewise, in England and Wales, the Police and Criminal Evidence Act (PACE) 1984 stipulates that suspects being interviewed must be informed of the nature of the offence.

In many cases where persons suspected of committing sexual abuse are truly guilty, shame and fear of exposure are likely to be driving factors underlying non-disclosure. Thus, it seems logical that the best way forward in cases where the suspects acknowledge some involvement in the alleged events, or a relationship with the victim, is to invite them (without assuming any wrongdoing) to give their version of the events or to explain the nature of their relationship with the alleged victim. This recommendation is consistent with a nonleading, open-ended approach (which is the 
benchmark of best practice in all prominent investigative interviewing protocols (Milne \& Bull, 1999)) and with the approach adopted by many clinicians to encourage disclosure of sensitive information in therapeutic settings (Royal College of Psychiatrists, 2004).

The value of using broad invitations when initially raising the topic of concern is twofold. First, open-ended invitations are perceived as non-threatening and less interrogative compared with a series of specific questions (ie, those that dictate what specific information is required and offer the interviewee little time to collect his or her thoughts). This is because open-ended questions portray a relationship where interviewees' perspectives are valued and heard and because open-ended questions allow truly guilty suspects to portray themselves in a positive light, thus lowering their defences (Kebbell, Powell, \& Wright, 2009. Second, open-ended questions minimise the risk that interviewers will raise specific case-related information (when discussing the allegation) in an attempt to confirm their preconceptions or prior knowledge (Meissner \& Kassin, 2004; Nickerson, 1998; Wason, 1960).

The risk of being leading when raising the topic of concern is heightened among interviews of sex offender suspects because these interviews take place well after the investigation has commenced (eg, after the elicitation of the victim statement). Moston, Stephenson, and Williamson (1992) noted (when analysing taped field interviews) that in cases where police officers perceived that there was strong evidence against the suspect, there was a tendency to commence the interview with an accusatorial style of interviewing and to confront the suspect with the 'proof' at the outset. These findings are paradoxical given that from a legal or policing perspective, a confession (which presumably is motivating the confronting style) is less rather than more important in cases where the officer has substantial evidence against the suspect. If interviewers who have strong evidence were to withhold mentioning this evidence at the outset, and were to focus on eliciting a detailed response to a broad allegation, this response could be potentially useful for establishing a verdict (Moston \& Stephenson, 1993). For example, if DNA evidence were available indicating prior contact between the victim and suspect, and yet the suspect strongly denied ever meeting the victim, this would raise doubt about the suspect's credibility in general. The lower credibility, in turn, would heighten the likelihood of a guilty verdict irrespective of whether the DNA linked the suspect to the particular sexual act that initiated the allegation of wrongdoing.

It needs to be kept in mind, however, that judgements about the credibility of the interviewee must be made with absolute caution at the investigative stage. For example, the Behavioural Analysis Interview is a widely used pre-interrogation process in the US for identifying whether or not a person is telling the truth or withholding relevant information. Substantial literature indicates, however, that professionals are poor at detecting deception (Akerhurst \& Vrij, 1999; Mann, Vrij, \& Bull, 2002; Vrij, Mann, Kristen, \& Fisher, 2007). This is due in part to the misconception of police officers that suspects who are being deceptive will be nervous and fidgety, when in fact the evidence shows that deceptive suspects tend to move less rather than more (Akerhurst \& Vrij; Mann, Vrij \& Bull). Further, embarrassment and aggression on the part of the suspect are often misconstrued as being indicative of guilt when these are also normal responses to discussion about sexual acts, or of being falsely accused of a criminal offence that carries a lengthy jail term (Kassin, 2005). 


\section{ELICITING NARRATIVE DETAIL}

Immediately after introducing the topic of concern, the interviewer's next goal should be to encourage a narrative account of the event or situation. A narrative account is that where the interviewee is given the opportunity to report what happened with little prompting from the interviewer, at his or her own pace, and without interruption (Fisher, 1995; Powell, Fisher, \& Wright, 2005). To elicit such an account, the interviewer uses open-ended questions (questions that require elaborate responses and, in general, keep the focus broad) to steer the interviewee to the next point in the story or gently to encourage the interviewee to provide further narrative information. Minimal non-verbal encouragers (eg, head nods, pauses, 'Mmmm', silence, 'Uh-huh', reflecting back phrases) and other behaviours that reinforce the interviewer's role as an interested naïve listener are important in enhancing the effectiveness of questions at this critical phase.

When given broad open-ended questions, adults with well-developed narrative skills tend to provide accounts of events in a logical sequence, while introducing the various elements that enhance the understanding of the naive listener. Such elements include: the setting, the initiating event, the interviewee's internal response, the plan of action and attempt at action, the direct consequences of this action and protagonists' reactions (Snow \& Powell, 2005). When the interviewee reaches the end of the story, the role of the interviewer is to extend the narrative by guiding the interviewee back to parts of the narrative and providing opportunities for further recall about issues or areas of potential interest (Powell \& Snow, 2007a).

Prior research has established several benefits associated with the elicitation of a narrative account. First, when an interviewee is given the opportunity to narrate his or her account freely, this gives the perception that he or she is being treated fairly which, in turn, facilitates rapport. For example, in a study involving in-depth interviews with convicted sex offenders, Kebbell, Hurren, and Mazerolle (2006) reported that the interview process was judged by these offenders to be more ethical and humane when the officer allowed the suspect to talk. Second, it is well established that details provided during free narrative are more likely to be accurate than responses to focused, short-answer questions. This is because open-ended questions encourage an elaborate or deep form of memory processing, allowing the interviewee to use a more stringent metacognitive level of control and minimising the potential for external contamination of the account by the interviewer (Lipton, 1977; Powell, Fisher, \& Wright, 2005). Third, open-ended questions reduce the risk of underestimating the interviewee's language limitations, and (because of their slower pace compared with specific questions) they allow the interviewee and interviewer time to collect their thoughts (Powell, Fisher, \& Wright, 2005).

Caution needs to be exercised when eliciting a narrative account to ensure that the interviewee does not steer off topic. Paedophiles, for example, may try to focus on describing their personal bonds and relationships (Benneworth, 2007), or violent rapists may focus on criticising the alleged victim's character and credibility. Experts in interviewing suggest that the process of steering the narrative towards the event or occurrence of sexual contact (if this has been acknowledged by the interviewee) could be facilitated by focusing the account on what happened (eg, 'Tell me what happened', 'What happened then?') as opposed to encouraging descriptive detail about a person (Powell \& Snow, 2007a, 2007b). In cases where the information provided is not sufficiently elaborate, the interviewee 
should be steered back to a predisclosed part of the event and gently encouraged to elaborate (eg, 'Tell me more about the part where ...'). The critical aspect of narrative questioning is that the interviewer does not dictate what specific information is required and the information is not challenged in any way (ie, the interviewer's role is merely to provide gentle probes to follow up areas of interest).

The process of encouraging an uncooperative or reluctant interviewee to talk (via an open-ended questioning approach) is extremely challenging. Indeed, the typical interviewer style (even after training in the use of open-ended questions) depicts an abundance of specific questions and interruptions of the interviewee's narrative account (Fisher, Geiselman, \& Raymond, 1987; Powell, Fisher, \& Wright, 2005). Although there is no published evidence to indicate what precipitates deviations from open-ended questioning in interviews with suspects, the work in the child interview arena suggests that the problem is multidimensional. It relates to the specificity of the information required for prosecution, the unfamiliar nature of the open-ended discourse style, and the complex distinction between open-ended versus specific questions (Wright \& Powell, 2006). Further, the child interview literature has shown a strong interrelationship between interviewer and interviewee behaviours such that 'don't know' or 'don't remember' responses can increase the likelihood of an interrogative or leading approach, which in turn can increase false reports (Gilstrap \& Ceci, 2005; Gilstrap \& Papierno, 2004). As with all interviewees, rather than challenge a suspect's claim of poor memory, it would be more fruitful (for the purpose of maintaining rapport and the interviewee's continued engagement in the interview) to move to another event-related topic and return to the issue at a later stage of the interview process.

\section{CLARIFICATION/SPECIFIC QUESTIONS}

Despite the superiority of open-ended questions, specific questions are usually a necessary part of the interview process. The function of these questions is to gather critical details that were omitted from the narrative account and to clarify inconsistencies occurring within the suspect's account and with respect to independent evidence obtained prior to the interview (Milne \& Bull, 1999). For reasons explained earlier, error rates inevitably increase with specific (as opposed to open-ended) questions (Stokoe \& Edwards, 2008). Adhering to several principles (as follows) may decrease potential error, thus enhancing the integrity and usefulness of the evidence obtained.

The first principle when asking specific questions is that simple language should be used. This involves using clear and concise questions and giving the suspect time to answer one question at a time. The importance of using simple language was emphasised in a cross-sectional study by Snow and Powell (2004a) which examined the oral language and social skills of 50 male juvenile offenders and 50 non-language-impaired controls. Overall, the offenders performed significantly worse on all measures, with over half of the young offenders being identified as language impaired compared with the mainstream participants (even though the mean age of the control group was significantly younger). Importantly, these language deficits could not be accounted for purely on the basis of IQ and were difficult to detect in the rapportbuilding phase. The implication of these findings is that, although the police in some jurisdictions (eg, Australia, England) are required to provide an independent support person when the offender has a cognitive or language impairment, the adequacy of current screening (given that no formal 
language assessment is routinely conducted) is dubious.

Second, as with open-ended questions, specific questions should be phrased in a non-leading and non-suggestive manner, especially given the strong association between language disorder and suggestibility (Gudjonnson, 2003). Leading questions are those that assume the existence of disputed facts (Heydon, 2004), and suggestive questions are those that imply what answer is required and/or coerce the interviewee to provide a certain response (Hughes-Scholes \& Powell, 2008). Third, questions need to be phrased (where possible) in a manner that allows the interviewee flexibility to report what happened or to provide an elaborate response. It is these dimensions that contribute to the superiority of openended questions (in terms of accuracy and detail of response) compared with specific questions, and yet individual specific questions can vary on these dimensions as well (Powell \& Snow, 2007a).

Finally, as the purpose of the interview is to gather evidence that can be used in court, it is vital to adhere to the relevant legislation and judicial rules governing the admissibility of that evidence. These legal requirements, which vary across jurisdictions, are mainly concerned with ensuring that any disclosure of self-incriminating information is voluntary (rather than coerced). For example, in the United Kingdom, common law allows police officers to be 'searching' and 'robust' but not bullying and oppressive ( $R$ v. Heron (1993), as cited in Williamson, 2006). Some jurisdictions permit officers to put the allegations to the suspect regardless of whether they accept the suspect's legal right to say 'no comment' (Heydon, 2004). The problem with the legislation is that terms such as 'persistent', 'searching' and 'robust' are broad in nature and interpretation of how they relate to actual questioning style is subjective. This may explain why awareness of legislation does not imply that legislation is being adhered to. For example, 10 per cent of a sample of 177 British police interviews with suspects was found by Clarke and Milne (2001) to be in breach of the Police and Criminal Evidence Act 1984.

One of the unique aspects of interviewing suspects as opposed to interviewing witnesses is that the interviewer is permitted to disclose specific evidence about the case. In doing so, the interviewer gives the suspect the chance to comment on the evidence and provide an explanation for it. In a suspect's interview, this is often referred to as the 'challenge phase' (Milne, Shaw, \& Bull, 2007), although it should not be interpreted literally as open disagreement or contradiction of the interviewee. Resistance or an unwillingness to talk stems from psychological blocks such as anxiety, apprehension, fear or anger (Shepherd, 1993), so any obvious challenge is likely to increase rather than decrease these emotional resistances (Oxburgh, Williamson, \& Ost, 2006; Shepherd).

Overall, the prior literature suggests that various methods may be effective in overcoming resistance to disclosure when presenting evidence, without violating the rights of the accused or increasing the likelihood of a false confession. First, adopting a humane, empathic, information-gathering approach is critical; an approach where the suspect has the confidence and 'mental space' to discuss any criminal activities that occurred (Holmberg \& Christianson, 2002; Shepherd, 1993). Interviewers are more likely to adhere to this approach if they are open to alternative explanations for contradictory evidence and do not assume that the suspect is lying. For example, rather than saying 'The victim says you did $\mathrm{X}$. Why did you do it?', it is advisable to say, 'The victim says $\mathrm{X}$. Tell me what you know about this' or 'Help me understand why [the victim] has said this'. The importance of a humane approach is no less important 
when the suspect becomes evasive or hostile. Indeed, when Powell (1999) interviewed several police officers who were perceived as being particularly good at engaging threatened and marginalised (eg, Australian Aboriginal) communities, courtesy, respect, patience and honesty were perceived by these officers to be their most valued professional assets.

Second, interviewers need to ensure that the evidence they present in the challenge phase of the interview is accurate. The importance of this was illustrated in a laboratory study conducted by Kebbell and Daniels (2006). In their study, 90 participants (university students) were asked to commit a mock crime (stealing a wallet) and were later presented with evidence from a witness who alleged having seen the offence. The participants were randomly assigned to one of three conditions: detailed correct, non-detailed correct and incorrect information by witnesses. Those presented with inaccurate evidence were less likely to confess to the crime, but the impact of correct identification (irrespective of how detailed) was negligible. In a similar study, Kebbell, Hurren, and Roberts (2006) found that participants who committed a mock crime of stealing a mobile phone were more likely to confess when presented with accurate information, but the level of evidential detail made no difference to confession rates. Taken together, these studies show that evidence disclosure can be risky, particularly if the evidence against a suspect is only weak and the interviewer commits to its accuracy.

Third, later presentation of evidence has been shown to be more effective than earlier disclosure of evidence (Hartwig et al., 2006). Specifically, Hartwig et al. showed that officers who were trained to withhold evidence until later in the interview were better at detecting deception (85.4 per cent deception-detection accuracy) than officers who presented evidence earlier in the interview (56.1 per cent accuracy). Hartwig et al. argued that this was due (in part) to the fact that when evidence is disclosed early on, the suspect becomes aware of what he or she should or should not say, and officers must therefore rely on non-verbal behaviour to assess the veracity of the suspect's account which is unreliable. Conversely, when the evidence was withheld until later in the interview, there was greater opportunity within the narrative account and other verbal responses for the suspects to contradict themselves which is a better indicator of confabulation.

In sum, the research reviewed so far suggests that to minimise interviewee resistance and maximise information that can be used in court, a humane informationgathering approach should be adopted and strong, accurate evidence should be disclosed later in the interview after the narrative account has been elicited and any clarifying questions have been asked. Not all practitioners, however, agree with this conclusion. For example, the Reid technique which is widely used in the US and Canada is a process aimed at eliciting a confession (in cases where there is evidence against the suspect) using psychological tactics that confront the interviewee openly and overcome resistance forcibly (Inbau, Reid, \& Buckley, 1986; Napier \& Adams, 1998). Within this model, the elicitation of a confession is seen as an important goal. The techniques include starting with a fixed view of the interviewee's guilt, disallowing the suspect to explain his or her 'innocence', interrupting denials and telling the suspect to 'listen to the evidence' (Inbau, Reid, \& Buckley). Other recommendations include the use of 'normalising statements', 'baiting questions' to encourage the suspect to change his or her earlier denial of guilt, rationalising behaviour (eg, 'I understand how you might have ...'), projecting responsibility onto another person (eg, 'she 
was being provocative'), minimising the seriousness of the crime (eg, 'accidents happen ...') and minimising the perceived consequences of confessing (Inbau, Reid, \& Buckley; Napier \& Adams; Vessel, 1998).

There is no doubt that the Reid technique has a major influence on suspects' decision to confess to a crime (Leo, 1996; Pearse \& Gudjonsson, 1999). For example, Leo analysed 182 police interviews with respect to the characteristics, context and outcome of police interrogations in the United States. It was found that suspects confessed in nearly all cases where the interviewer appealed to the suspect's conscience; and praise, flattery and offering of moral or psychological justifications for the suspect's offence (as suggested by the Reid technique) also played a strong role. However, the reason for the high percentage of confessions when using these techniques is an issue of contention. It cannot be ruled out that victim evidence (the main evidence in these trials) was inaccurate, and there are sufficient case studies to demonstrate a relationship between coercive techniques and false confessions (Gudjonsson, 1999; Kassin, 1997; Milne \& Bull, 1999; Russano, Meissner, Narchet, \& Kassin, 2005). Indeed, the use of deals or minimisation is claimed to reduce the diagnostic value of an elicited confession by 74 per cent (Kassin \& Gudjonsson, 2004). Short-term benefits of falsely confessing include escaping an aversive situation, avoiding implied threats or gaining promised rewards (Kassin \& Gudjonsson). Furthermore, psychological tactics may result in a suspect's answers not being voluntary, ${ }^{3}$ subsequently rendering the evidence inadmissible in all courts in Australia and the UK (Heydon, 2004).

Within the child literature, the use of leading questions has been recommended by some as a last resort, if there is evidence that the child is abused and no disclosure has been made in response to less coercive tactics (Roberts \& Glasgow, 1993). However, the evidence to support the use of coercive tactics in suspects' interviews, even later in the interview, is negligible. Analysis of hundreds of interviews suggests that most suspects who deny the offence at the beginning of the interview tend also to deny the offence at the end of the interview, irrespective of the techniques that are used. Further, those who do confess often do so spontaneously at the beginning of the interview, prior to any specific prompting (Baldwin, 1993; Moston, Stephenson, \& Williamson, 1992; Pearse, Gudjonsson, Clare, \& Rutter, 1998). This suggests that a suspect's decision to confess is largely determined by processes operating prior to the commencement of the interview, rather than the interview process itself.

\section{ClOSURE}

The importance of ensuring appropriate closure of an investigative interview with a suspect should not be underestimated. This stage determines the future cooperation of the suspect, which is critical should the interviewer have reason to talk to the suspect again (Clarke \& Milne, 2001). In this phase, the information provided during the interview is summarised (so that the interviewee can correct any previously unidentified misunderstandings), the interviewee is given the chance to ask questions and forensic evidence (such as fingerprints) may also be requested.

During the closure phase, the suspect is also informed of future processes. In cases where there is strong evidence against the suspect, officers may charge the suspect with the alleged offence or offences irrespective of any admission (Moston \& Stephenson, 1993). In cases where the officer elects not to charge the suspect, it would be appropriate to thank the interviewee for his or her participation and to invite the interviewee to 
contact police again if he or she has any further information. This reaffirms the humane, information-gathering and openminded approach, which is critical for maintaining rapport (thus increasing the likelihood of the suspect being cooperative in future interviews).

\section{CONCLUSION}

Much remains to be understood about what constitutes best-practice interviewing of suspected sex offenders. As this review has highlighted, the research is still in its infancy and there are several limitations of the existing work to date. Most of the work on interviewing suspects emanates directly from interviews with convicted offenders (which constitutes a very select group), from experiential knowledge reflecting personal insights gained from observing interviews, or from modelling the characteristics of interviews that have been known to lead to false confessions. The few empirical studies that have directly examined the relationship between interviewee and interviewer response styles have evolved from examining the behaviour of lay persons (eg, university students) about mock crimes, thus raising concerns about ecological validity.

Nonetheless, this paper has offered an initial (tentative) guide to what constitutes 'best-practice' investigative interviews of suspected sex offenders, integrating the findings from across different streams (law, linguistics, clinical and investigative interviewing). The next step, before refining or elaborating on these guidelines, is to try to make sense of the discrepancy that seems to exist between the recommendations in this paper and actual police interview practice, and to conduct more research on the interviewing of sex offenders, particularly those who offend against children.

\section{AcKNoWLedgement}

The paper was supported by an Australian Research Council Linkage Grant (LP0775248). Thanks to Patrick Tidmarsh for his comments on an earlier draft of this paper.

\section{Notes}

1 Suggestibility is defined as the degree to which an interviewee's encoding, storage, retrieval and/or reporting of events can be influenced by a range of social and psychological factors (Ceci \& Bruck, 1993).

2 In the child literature this is achieved by having the child recall in detail an innocuous event such as a recent holiday (Sternberg et al., 1997). With adult interviewees, this can be achieved by encouraging elaboration when eliciting personal, biographical information from the interviewee (Fisher \& Geiselman, 1992).

3 According to law, 'voluntary' refers to confessions 'made in the exercise of free choice and not because the will of the accused has been overborne or his statement is made as the result of duress, intimidation, persistent importunity or sustained or undue insistence or pressure' (R v. Lee (1950) 82 CLR 133 at 144).

\section{References}

Akerhurst, L., \& Vrij, A. (1999). Creating suspects in police interviews. Journal of Applied Social Psychology, 29, 192-210.

Australian Bureau of Statistics (2004). Sexual Assault in Australia: A Statistical Overview (No. 4523.0) Canberra, Australian Capital Territory: Author.

Baldwin, J. (1992). Video-taping of police interviews with suspects: An evaluation. London: Home Office.

Baldwin, J. (1993). Police interview 
techniques; establishing truth or proof? (United Kingdom). British Journal of Criminology, 33, 325-352.

Benneworth, K. (2007). Just good friends: Managing the clash of discourses in police interviews with paedophiles. In J. Cotterill (Ed.), The Language of Sexual Crime (pp. 4262). Hampshire: Palgrave Macmillan.

Bennis, W. G., Berlew, D. E., Schein, E. H., \& Steele, F. I. (1973). Interpersonal Dynamics: Essays and Readings on Human Interaction (3rd ed.). Illinois: The Dorsey Press.

Bruck, M., \& Melnyk, L. (2004). Individual differences in children's suggestibility: A review and synthesis. Applied Cognitive Psychology, 18, 947-996.

Bryan, K. (2004). Preliminary study of the prevalence of speech and language difficulties in young offenders. International Journal of Language and Communication Disorders, 39, 391-400.

Bryan, K., Freer, J., \& Furlong, C. (2007). Language and communication difficulties in juvenile offenders. International Journal of Language and Communication Disorders, 42, 505-520.

Ceci, S. J., \& Bruck, M. (1993). Suggestibility of the child witness: A historical review and synthesis. Psychological Bulletin, 113, 403-439.

Clarke, C., \& Milne, R. (2001). National Evaluation of the PEACE Investigative Interviewing Course. London: Home Office.

Cohen, L. J., McGeoch, P. G., Watras-Gans, S., Acker, S., Poznansky, O., Cullen, K., et al. (2002). Personality impairment in male pedophiles. Journal of Clinical Psychiatry, 63, 912-919.

Dunsieth, N. W., Jr., Nelson, E. B., BrusmanLovins, L. A., Holcomb, J. L., Beckman, D., Welge, J. A., et al. (2004). Psychiatric and Legal Features of 113 Men Convicted of Sexual Offenses. Journal of Clinical Psychiatry, 65, 293-300.

Eades, D. (1992). Aboriginal English and the law [Abstract]. Brisbane: Queensland Law Society.

Ede, R., \& Shepherd, E. (2000). Active Defence (2nd ed.). London: Law Society Publishing.
Ellis, A. (1954). Interrogation of sex offenders. Journal of Criminal Law and Criminology and Police Science, 45, 42-47.

Emmers-Sommer, T. M., Allen, M., Bourhis, J., Sahlstein, E., Laskowski, K. P., Falato, W. L., et al. (2004). A meta-analysis of the relationship between social skills and sexual offenders. Communication Reports, 17, 1-10.

Fazel, S., Sjostedt, G., Langstrom, N., \& Grann, M. (2007). Severe mental illness and risk of sexual offending in men: A casecontrol study based on Swedish national registers. Journal of Clinical Psychiatry, 68, 588-596.

Fisher, D., Beech, A., \& Browne, K. (1999). Comparison of sex offenders to nonoffenders on selected psychological measures. International Journal of Offender Therapy and Comparative Criminology, 43, 473-491.

Fisher, R. P. (1995). Interviewing victims and witnesses of crime. Psychology, Public Policy, and Law, 1, 732-764.

Fisher, R. P., \& Geiselman, R. E. (1992). Memory-enhancing techniques in investigative interviewing: The cognitive interview. Springfield, IL: C. C. Thomas.

Fisher, R. P., Geiselman, R. E., \& Raymond, D. S. (1987). Critical analysis of police interviewing techniques. Journal of Police Science and Administration, 15, 177-185.

Gilstrap, L. L., \& Ceci, S. J. (2005). Reconceptualizing children's suggestibility: Bidirectional and temporal properties. Child Development, 76, 40-53.

Gilstrap, L. L., \& Papierno, P. B. (2004). Child characteristics on children's and adults' interview behaviours. Applied Cognitive Psychology, 18, 1059-1078.

Grice, P. (1975). Logic and conversation. In P. Cole \& J. Morgan (Eds.), Syntax and Semantics (Vol. 3, pp. 43-58). New York: Academic Press.

Gudjonsson, G. H. (1999). The making of a serial false confessor: The confessions of Henry Lee Lucas. Journal of Forensic Psychiatry and Psychology, 10, 416-426.

Gudjonsson, G. H. (2003). The Psychology of Interrogations, Confessions, and Testimony. Chichester: John Wiley \& Sons. 
Gudjonsson, G. H., \& Clark, N. K. (1986). Suggestibility in police interrogation: A social psychological model. Social Behaviour, 1, 83-104.

Gudjonsson, G. H., \& Sigurdsson, J. F. (2000). Differences and similarities between violent offenders and sex offenders. Child Abuse and Neglect, 24, 363-372.

Hartwig, M., Granhag, P. A., Stromwall, L. A., \& Kronkvist, O. (2006). Detecting deception via strategic disclosure. Law and Human Behavior, 29, 469-484.

Heydon, J. D. (2004). Cross on Evidence (7th ed.). Sydney: LexisNexis Butterworths.

Higendorf, E. L., \& Irving, B. (1981). A decision-making model of confessions. In M. A. Lloyd-Bostock (Ed.), Psychology in Legal Contexts: Application and Limitations (pp. 67-84). London: Macmillan.

Holmberg, U., \& Christianson, S. (2002). Murderers' and sexual offenders' experiences of police interviews and their inclination to admit or deny crimes. Behavioral Sciences and the Law, 20, 31-45.

Hoyano, L., \& Keenan, C. (2007) Child Abuse: Law and Policy across Boundaries. Oxford University Press.

Hughes-Scholes, C. H., \& Powell, M. B. (2008). An examination of the types of leading questions used by investigative interviewers of children. Policing: An International Journal of Police Strategies and Management, 31, 210-225.

Inbau, F. E., Reid, J. E., \& Buckley, J. P. (1986). Criminal Interrogation and Confessions (3rd ed.). Baltimore: Williams and Wilkins.

Kassin, S. M. (1997). The psychology of confession evidence. American Psychologist, 52, 221-233.

Kassin, S. M. (2005). On the Psychology of Confessions: Does Innocence Put Innocents at Risk? American Psychologist, 60(3), 215-228.

Kassin, S. M., \& Gudjonsson, G. H. (2004). The psychology of confessions: A review of the literature and issues. Psychological Science in the Public Interest, 5, 33-67.

Kebbell, M., Alison, L., Hurren, E., \& Mazerolle, P. (in press). Sex offenders' perceptions of police interviewing.
Kebbell, M., \& Daniels, T. (2006). Mocksuspects' decisions to confess: the influence of eyewitness statements and identifications. Psychiatry, Psychology and Law, 13, 261-274.

Kebbell, M.R, Hurren, E. J., \& Mazerolle, P. (2006). Sex offenders' perceptions of police interviewing: Implications for improving the interviewing effectiveness. The Canadian Journal of Police and Security Services, 4, 67-75.

Kebbell, M., Hurren, E., \& Roberts, S. (2006). Mock-suspects' decisions to confess: the accuracy of eyewitness evidence is critical. Applied Cognitive Psychology, 20, 477-486.

Kebbell, M., Powell, M., \& Wright, R. (2009). Police officers' perceptions of how suspected sex offenders should be interviewed (Under review).

Kinsey, A. C., Pomeroy, W. B., \& Martin, C. E. (1948). Sexual Behavior in the Human Male. Philadelphia: W. B. Saunders.

Leo, R. A. (1996). Inside the interrogation room. Journal of Criminal Law and Criminology, 86, 266-303.

Lipton, R. (1977). On the psychology of eyewitness testimony. Journal of Applied Psychology, 62, 90-95.

Mann, S., Vrij, A., \& Bull, R. (2002). Suspects, lies, and videotape: An analysis of authentic high-stake liars. Law and Human Behavior, 26, 365-376.

McGrath, R. J. (1990). Assessment of sexual aggressors: practical clinical interviewing strategies. Journal of interpersonal violence, 7 , 507-519.

Meissner, C. A., \& Kassin, S. M. (2004). 'You're guilty, so just confess!' Cognitive and behavioral confirmation biases in the interrogation room. In G. D. Lassiter (Ed.), Interrogations, Confessions and Entrapment (pp. 85-102). New York: Kluwer Academic.

Milne, R., \& Bull, R. (1999). Investigative interviewing: Psychology and practice. Chichester: Wiley.

Milne, R., Shaw, G., \& Bull, R. (2007) Investigative interviewing: The role of psychology. In D. Carson, R. Milne, F. Pakes, \& K. Shalev (Eds.), Applying 
psychology to criminal justice (65-81).

Chichester: Wiley.

Moston, S., \& Stephenson, G. M. (1993). The changing face of police interrogation. Journal of Community and Applied Social Psychology, 3, 101-115.

Moston, S., Stephenson, G. M., \& Williamson, T. (1992). The effect of case characteristics on suspect behaviour during police questioning. British Journal of Criminology, 32, 23-40.

Napier, M. R., \& Adams, S. H. (1998). Magic words to obtain confessions. FBI Law Enforcement Bulletin, 67, 11-15.

Nield, R., Milne, R., Bull, R., \& Marlow, K. (2003). The Youth Justice and Criminal Evidence Act 1999 and the interviewing of vulnerable groups: A practitioner's perspective. Legal and Criminological Psychology, 8, 223-228.

Nickerson, R. S. (1998). Confirmation bias: A ubiquitous phenomenon in many guises. Review of General Psychology, 2(2), 175-220.

Ord, B., Shaw, G., \& Green, T. (2004). Investigative Interviewing Explained (2nd ed.). Australia: LexisNexis Butterworths.

Oxburgh, G., Williamson, T., \& Ost, J. (2006). Police officers' use of emotional language during child sexual abuse investigations. Journal of Investigative Psychology and Offender Profiling, 3, 35-45.

Paddock, J. R., \& Terranova, S. (2001). Guided visualization and suggestibility: Effect of perceived authority on recall of autobiographical memories. Journal of Genetic Psychology, 162(3), 347-356.

Pearse, J., \& Gudjonsson, G. H. (1999). Measuring influential police interviewing tactics: A factor analytic approach. Legal and Criminological Psychology, 4, 221-238.

Pearse, J., Gudjonsson, G. H., Clare, C. H., \& Rutter, S. (1998). Police interviewing and psychological vulnerabilities: Predicting the likelihood of a confession. Journal of Community and Applied Social Psychology, 8, 1-21.

Poole, D. A., \& Lamb, M. E. (1998). Children as witnesses: the tragedy and the dilemma. In D. A. Poole \& M. E. Lamb (Eds.), Investigative Interviews of Children, $A$ Guide for
Helping Professionals (pp. 7-32). Washington, DC: American Psychological Association.

Powell, M. B. (1999). Guidelines for conducting investigative interviews with Aboriginal people. A report submitted to the Northern Territory Law Society (Public Purposes Trust).

Powell, M. B. (2000). PRIDE: The essential elements of a forensic interview with an Aboriginal person. Australian Psychologist, 35, 186-192.

Powell, M. B. (2003). A guide to introducing the topic of an interview about abuse with a child. Australian Police Journal, 57, 259-263.

Powell, M. B., \& Bartholomew, T. (2003). Interviewing and assessing clients from different cultural backgrounds: Guidelines for all forensic professionals. In R. Bull \& D. Carson (Eds.), Psychology in Legal Contexts (2nd ed., pp. 625-644). London: Wiley.

Powell, M. B., Fisher, R. P., \& Wright, R. (2005). Investigative interviewing. In N. Brewer \& K. D. Williams (Eds.), Psychology and Law: An Empirical Perspective (11-43). New York: Guilford Press.

Powell, M. B., \& Lancaster, S. (2003). Guidelines for interviewing children during child custody evaluations. Australian Psychologist, 38, 46-54.

Powell, M. B., \& Snow, P. C. (2007a). Guide to questioning children during the freenarrative phase of an investigative interview. Australian Psychologist, 42, 57-65.

Powell, M. B., \& Snow, P. (2007b).

Recommendations for eliciting a disclosure of abuse from a young child. Australian Police Journal, 61, 76-80.

Quinn, J. F., Forsyth, C. J., \& Mullen-Quinn, C. (2004). Societal reaction to sex offenders: A review of the origins and results of the myths surrounding their crimes and treatment amenability. Deviant Behavior, 25, 215-232.

Richardson, G., \& Kelly, T. P. (1995). The relationship between intelligence, memory and interrogative suggestibility in young offenders. Psychology, Crime \& Law, 4, 283-290. 
Roberts, H., \& Glasgow, D. (1993). Gathering evidence from children: A systematic approach. Issues in Criminological \& Legal Psychology, 20, 10-14.

Roberts, K. P., Lamb, M. E., \& Sternberg, K. J. (2004). The effects of rapport-building style on children's reports of a staged event. Applied Cognitive Psychology, 18, 189-202.

Royal College of Psychiatrists. (2004). Looking at the assessment of sex offenders. Training DVD. Dawson Films. ISBN 1 904671195

Russano, M. B., Meissner, C. A., Narchet, F. M., \& Kassin, S. M. (2005). Investigating true and false confessions within a novel experimental paradigm. Psychological Science in the Public Interest, 16, 481-486.

Sanger, D., Moore-Brown, B., \& Alt, E. (2000). Advancing the discussion on communication and violence. Communication Disorders Quarterly, 22, 43-48.

Shepherd, E. (1991). Ethical interviewing. Policing, 7, 42-60.

Shepherd, E. (1993). Aspects of police interviewing. Issues in Criminological and Legal Psychology, 18, 27-45.

Snow, P., \& Powell, M. (2004a). Interviewing juvenile offenders: the importance of oral language competence. Current Issues in Criminal Justice, 16, 220-225.

Snow, P. C., \& Powell, M. B. (2004b). Developmental language disorders and adolescent risk: A public-health advocacy role for speech pathologists? Advances in Speech-Language Pathology, 6, 221-229.

Snow, P. C., \& Powell, M. B. (2005). What's the story? An exploration of narrative language abilities in male juvenile offenders. Psychology, Crime \& Law, 11, 239-253.

Stein, N. L., \& Glen, C. G. (1979). An analysis of story comprehension. In R. Freedle (Ed.), New Directions in Discourse Processing (53-120). New Jersey: Ablex.

Stephenson, G. M., \& Moston, S. (1993). Attitudes and assumptions of police officers when questioning criminal subjects. Issues in Criminological and Legal Psychology. 18, 30-36.
Sternberg, K., Lamb, M., Hershkowitz, I., Yudilevitch, L., Orbach, Y., Esplin, P., et al. (1997). Effects of Introductory Style on Children's Abilities to Describe Experiences of Sexual Abuse. Child Abuse and Neglect, 21, 1133-1146

Stokoe, E., \& Edwards, D. (2008). 'Did you have permission to smash your neighbour's door?' Silly questions and their answers in police-suspect interrogations. Discourse Studies, 10, 89-111.

Swaffer, T., Hollin, C., Beech, A., Beckett, R., \& Fisher, D. (1999). An exploration of child sexual abusers cognitive distortions with special reference to the role of anger. Journal of Sexual Aggression, 4, 31-44.

The Response to Rape: Detours on the Road to Equal Justice. (1993). A majority staff report prepared for the use of the Committee on the Judiciary, United States Senate, 103rd Congress, 1st Session.

Vessel, D. (1998). Conducting successful interrogations. FBI Law Enforcement Bulletin, 67(10), 1-6.

Vrij, A. (2003). 'We will protect your wife and child, but only if you confess': Police interrogations in England and the Netherlands. In P. J. van Koppen \& S. D. Penrod (Eds.), Adversarial Versus Inquisitorial Justice: Psychological Perspectives on Criminal Justice Systems (55-81). New York: Springer.

Vrij, A., Mann, S., Kristen, S., \& Fisher, R. P. (2007). Cues to deception and ability to detect lies as a function of police interview styles. Law and Human Behavior, 31, 499-518.

Walters, S. B. (2002). Principles of kinesic interview and interrogation (2nd ed.). Washington, DC: CRC Press.

Ward, T., Hudson, S. M., \& Marshall, W. L. (1996). Attachment style in sex offenders: A preliminary study. Journal of Sex Research, $33,17-26$.

Ward, T., Hudson, S. M., Johnston, L, \& Marshall, W. L. (1997). Cognitive distortions in sex offenders: An integrative review Clinical Psychology Review, 17, 479-507.

Wason, P. C. (1960). On the failure to eliminate hypotheses in a conceptual task. 
Quarterly Journal of Experimental Psychology, 12, 129-140.

Williamson, T. (2006). Investigative Interviewing: Rights, Research and Regulation. Cullompton: Willan.

Wilson, C., \& Powell, M. (2001). A Guide to Interviewing Children. Australia: Allen \& Unwin.
Wright, R., \& Powell, M. (2006). Investigative interviewers' perceptions of their difficulty in adhering to open-ended questions with child witnesses. International Journal of Police Science and Management, 8(4), 316-325.

Yeschke, C. L. (2003). The Art of Investigative Interviewing (2nd ed.). USA: ButterworthHeinemann. 